\title{
Simulation and Experimental Validation of solar water heater operating with selected Phase Change Materials
}

\author{
Tochukwu C. Nwachukwu ${ }^{1}$ and Abasiafak N. Udosen ${ }^{1,2}$ \\ ${ }^{1}$ Department of Mechanical Engineering, University of Nigeria Nsukka, 410001, Nigeria \\ ${ }^{2}$ Department of Mechanical Engineering, University of Cape Town, 7700, South Africa
}

\begin{abstract}
Solar water heaters are widely known for their application in the domestic sector for heating water using free sunlight. However, the stochastic nature of sunlight especially in the tropical parts of the world, has created the need for some form of thermal energy storage to buffer the effect of the randomly varying solar insolation, and also to ensure a steady hot water delivery even during the night time, when the solar insolation is absent. This paper experimentally and numerically studies (using CFD software) the behavior of a solar water heater operating in the tropical climate of Nsukka, Nigeria, (Latitude $6.854^{\circ} \mathrm{N}$ longitude $7.29^{\circ} \mathrm{E}$ ), incorporated with cetyl alcohol (Melting point: $47^{\circ} \mathrm{C}-50^{\circ} \mathrm{C}$ ), palmitic acid (Melting point: $63^{\circ} \mathrm{C}-65^{\circ} \mathrm{C}$ ) Myristic acid (Melting point: $50^{\circ} \mathrm{C}-53^{\circ} \mathrm{C}$ ) and stearic acid (Melting point: $69^{\circ} \mathrm{C}-70^{\circ} \mathrm{C}$ ) as thermal energy stores. The experiments were carried out during the rainy season, with an average relative humidity of $83.26 \%$ and solar irradiance of $250 \mathrm{~W} / \mathrm{m}^{2}$. The maximum average collector box temperature recorded was $55.62^{\circ} \mathrm{C}$. The thermal performance of a solar water heater operating with cetyl alcohol, palmitic acid, myristic acid and stearic acid was measured, paying specific attention to their charging performance and hot water delivery during nighttime. A CFD model is also developed using ANSYS FLUENT and is used to simulate the collector box, hot water and PCM temperatures. The CFD model developed, predicted the PCM and hot water temperatures with a Root Means Square Error of $3.05^{\circ} \mathrm{C}$ and $3.64^{\circ} \mathrm{C}$ respectively, and with a Nash Sutcliffe accuracy of $98 \%$ and $99 \%$ respectively.
\end{abstract}

Keywords: Energy Storage, CFD, Solar Water Heater, Latent Heat, Collector, Solar Energy

DOI: $10.7176 / \mathrm{JETP} / 10-5-05$

Publication date:September $30^{\text {th }} 2020$

\section{Introduction}

Solar water heaters utilize free sunlight to heat water [1]. This technology provides reduced fuel costs, by removing or eliminating the need for wood fuel, gas or electricity and has proven in recent times to be a viable environmental and economic solution for domestic and industrial utilizations. However, solar energy is diurnal and comes with its own intermittencies, and these affect the performance of solar water heaters, especially during the night and cloudy hours of the day. Thus, there is need for some form of efficient energy storage, in order to make up for these intermittencies. So far, the widely used storage methods are sensible storages [2]. Through series of tests and experiments, Phase Change Materials (PCMs) can be considered as an ideal solution for thermal management challenges [3]. Latent heat thermal storage, has an advantage of high energy density with small volume and in principle, allows for energy storage at a nearly constant (phase change) temperature during melting and solidification [4]. The enormous advantages of PCMs have led to several critical studies of its chemical and thermophysical properties in other to handle the task of selecting the perfect PCM required for solar water heating integrations at various climatic conditions. Certain solar water heating applications require that choice PCMs must be commercially and readily available within the region, non-toxic, have good thermal properties, and must operate perfectly within the average temperature range of the region. However, according to [4], PCM based storage systems may require standardized experimental procedures with high response devices used to characterize the charging and discharging phases. This is because phase-change with very sharp gradients over very small regions may occur [4]. In the attempt to provide a cost-effective approach in the modelling of the melting and solidification of PCMs, several numerical methods, which can be implemented using Computational Fluid Dynamics (CFD) software packages to track the operation of phase change incorporated into solar water heaters with a high degree of accuracy [5].

\section{Materials and Methods}

\subsection{Experimental Evaluation of Solar Hot Water System Performance}

The solar water heater incorporated with phase change materials is investigated. A total of 9 copper tubes (1026 
$\mathrm{mm}$ in length) are consecutively filled with PCMs and are inserted into the annulus of the absorber tubes of the solar water heater. The specifications of the copper PCM tubes are given in table 1. The absorber tubes themselves are made up of aluminium and are arranged in a parallel configuration. Water flows over the exterior surface of the PCM tubes, within the annulus of the aluminium absorbers. This process transfers heat via conduction to the PCMs during the high solar insolation periods of the day, causing them to melt, storing the energy as both sensible and latent heat. The collector box is made up of wood, with the interior surface painted with black paint to ensure a high absorptivity of solar radiation from the sun. The top of the collector box is covered with Perspex glass of thickness $5 \mathrm{~mm}$ and transmissivity 0.85 . The solar collector is inclined at an angle of $22^{\circ} \mathrm{C}$ and set to face the South. This angle of inclination, according to [6] is optimum for a thermosyphon solar collector box operating in Nsukka region. The system is charged with cold water at the beginning of each day, and the operations of the solar water heater are monitored for 16 hours ( 8 am to 12 midnight) daily for two months.

The instrumentation of the experimental set up consist as follows:

- Fifteen (15) Type K thermocouples, which are used for detecting the variations in temperature in essential parts of the system. The type $\mathrm{k}$ thermocouples used, have a standard error of $+/-2.2^{\circ} \mathrm{C}$ or $+/-0.75 \%$. Five of the thermocouples are placed in the PCM chamber and are used to monitor the melting and solidification of the PCM. Five others are placed at different points within the collector box, to measure the temperature build-up inside the collector, during the day. One thermocouple is used to monitor the hot water outlet temperature, while the others measure the water inlet, storage tank, and ambient temperatures.

- A solar meter with data retention capabilities is used to log the solar insolation at intervals of 30 minutes during the day.

- A data logger with a 15-temperature channel capacity alongside a relative humidity monitoring feature, which processes and stores input from various input sensors with 24-hour format time appendages.

\subsection{CFD Simulation of Solar Water Heater with the various PCMs}

The performance of the solar water heater under the same weather conditions was studied numerically using ANSYS FLUENT CFD software. ANSYS FLUENT has a general algorithm to all fluid flow problems. This algorithm gives an overall view of the stages involved in performing numerical simulations of physical flow problems. The decisions made at the various stages of the simulation, however, are influenced by the unique nature of the flow problem being modelled. The simulation study made use of the CFD model detailed below. For the sake of experimental validation with the available data recorded during the testing period, ANSYS Solar Radiation Model was not employed as this assumes a clear sky condition which was not the case during the testing period. Rather, the temperature builds up in the collector box was recorded experimentally and used as input parameters on the surface of the solar water heater absorber tubes. This helped consider the variations and fluctuations in the weather conditions that were prevalent during the rainy testing period.

\subsubsection{Simulation of the hot water and PCM temperatures during the day}

The model used for this simulation, comprises of a copper PCM tube housed inside an aluminum pipe, in a concentric configuration. Water flows over the exterior of the PCM housing within the annulus of the aluminum pipe at the rate of $0.0123 \mathrm{~kg} / \mathrm{sec}$. A transient temperature boundary condition is set at the external surface of the outer aluminum pipe. This varying temperature data is obtained from the experimental data as earlier mentioned. Both the temperature of the water flowing within the pipe and the PCM are monitored. The material properties of the various parts of the solar water heater are tabulated in table 1.

Table 1. Absorber tube and PCM Chamber properties

\begin{tabular}{|l|l|l|}
\hline Property & Aluminum & Copper \\
\hline Density & $2700 \mathrm{~kg} / \mathrm{m}^{3}$ & $8933 \mathrm{~kg} / \mathrm{m}^{3}$ \\
Thermal Conductivity & $237 \mathrm{~W} / \mathrm{m}-\mathrm{K}$ & $401 \mathrm{~W} / \mathrm{m}-\mathrm{K}$ \\
Specific Heat capacity & $903 \mathrm{~J} / \mathrm{kg} \mathrm{K}$ & $385 \mathrm{~J} / \mathrm{kg} \mathrm{K}$ \\
Thickness & $3 \mathrm{~mm}$ & $2 \mathrm{~mm}$ \\
External diameter & $16 \mathrm{~mm}$ & $10 \mathrm{~mm}$ \\
Length & $1120 \mathrm{~mm}$ & $1500 \mathrm{~mm}$ \\
\hline
\end{tabular}


Table 2. Thermophysical properties of Phase Change Materials

\begin{tabular}{l|l|l|l|l}
\hline & Stearic Acid & Palmitic Acid & Myristic Acid & Cetyl Alcohol \\
\hline Density (solid) & $850 \mathrm{~kg} / \mathrm{m}^{3}$ & $940 \mathrm{~kg} / \mathrm{m}^{3}$ & $853 \mathrm{~kg} / \mathrm{m}^{3}$ & $976 \mathrm{~kg} / \mathrm{m}^{3}$ \\
Density (liquid) & $858 \mathrm{~kg} / \mathrm{m}^{3}$ & $839 \mathrm{~kg} / \mathrm{m}^{3}$ & $841 \mathrm{~kg} / \mathrm{m}^{3}$ & $940 \mathrm{~kg} / \mathrm{m}^{3}$ \\
Melting temperature range & $53^{\circ} \mathrm{C}-55^{\circ} \mathrm{C}$ & $68^{\circ} \mathrm{C}-70^{\circ} \mathrm{C}$ & $62^{\circ} \mathrm{C}-63^{\circ} \mathrm{C}$ & $49^{\circ} \mathrm{C}-50^{\circ} \mathrm{C}$ \\
Specific heat capacity (Solid) & $1.78 \mathrm{~kJ} / \mathrm{kg} \mathrm{K}$ & $2.83 \mathrm{~kJ} / \mathrm{kg} \mathrm{K}$ & $2.71 \mathrm{~kJ} / \mathrm{kg} \mathrm{K}$ & $2.89 \mathrm{~kJ} / \mathrm{kg} \mathrm{K}$ \\
Specific heat capacity (Liquid) & $2.48 \mathrm{~kJ} / \mathrm{kg} \mathrm{K}$ & $2.38 \mathrm{~kJ} / \mathrm{kg} \mathrm{K}$ & $2.73 \mathrm{~kJ} / \mathrm{kg} \mathrm{K}$ & $3.2 \mathrm{~kJ} / \mathrm{kg} \mathrm{K}$ \\
Thermal Conductivity (Solid) & $0.2 \mathrm{~W} / \mathrm{m}^{2} \mathrm{~K}$ & $0.29 \mathrm{~W} / \mathrm{m}^{2} \mathrm{~K}$ & $0.15 \mathrm{~W} / \mathrm{m}^{2} \mathrm{~K}$ & $0.1323 \mathrm{~W} / \mathrm{m}^{2} \mathrm{~K}$ \\
Thermal Conductivity (Liquid) & $0.2 \mathrm{~W} / \mathrm{m}-\mathrm{K}$ & $0.30 \mathrm{~W} / \mathrm{m}-\mathrm{K}$ & $0.55 \mathrm{~W} / \mathrm{m}-\mathrm{K}$ & $0.1309 \mathrm{~W} / \mathrm{m}-\mathrm{K}$ \\
Enthalpy of fusion & $173.4 \mathrm{KJ} / \mathrm{kg} \mathrm{K}$ & $198.80 \mathrm{~kJ} / \mathrm{kg} \mathrm{K}$ & $208.0 \mathrm{~kJ} / \mathrm{kg} \mathrm{K}$ & $207.39 \mathrm{~kJ} / \mathrm{kg} \mathrm{K}$ \\
Viscosity & $7.21 \mathrm{e}-3 \mathrm{~kg} / \mathrm{m}-\mathrm{s}$ & $7.79 \mathrm{e}-3 \mathrm{~kg} / \mathrm{m}-\mathrm{s}$ & $7.8 \mathrm{e}-6 \mathrm{~kg} / \mathrm{m}-\mathrm{s}$ & $5.3 \mathrm{e}-3 \mathrm{~kg} / \mathrm{m}-\mathrm{s}$ \\
Thermal expansivity & $8.6 \mathrm{e}-6 \mathrm{~K}{ }^{-1}$ & $3.6 \mathrm{e}-3 \mathrm{~K}-1$ & $1.3 \mathrm{e}-6 \mathrm{~K}{ }^{-1}$ & $2.6 \mathrm{e}-6 \mathrm{~K}{ }^{-1}$ \\
\hline
\end{tabular}

Table 3. Simulation Boundary Conditions

\begin{tabular}{l|l|l|l|l|l}
\hline & \multicolumn{2}{l|}{ Boundary Conditions } & \multicolumn{2}{l}{ Inlet Flow Conditions } \\
\hline & $\begin{array}{l}\text { Wall-Exterior Pipe- } \\
\text { Water }\end{array}$ & $\begin{array}{l}\text { Interior } \\
\text { Pipe } \\
\text { Surface }\end{array}$ & $\begin{array}{l}\text { Exterior Pipe } \\
\text { Surface }\end{array}$ & Fluid Name & Water \\
\hline $\begin{array}{l}\text { WALL } \\
\text { THICKNESS }\end{array}$ & $0.001 \mathrm{~m}$ & $0.001 \mathrm{~m}$ & $0.001 \mathrm{~m}$ & $\begin{array}{l}\text { Mass Flow } \\
\text { Rate }\end{array}$ & $0.00123 \mathrm{~kg} / \mathrm{s}$ \\
\hline MATERIAL NAME & aluminium & 3 & aluminium & $\begin{array}{l}\text { Total } \\
\text { Temperature }\end{array}$ & $298 \mathrm{~K}$ \\
\hline $\begin{array}{l}\text { THERMAL BC } \\
\text { TYPE }\end{array}$ & 3 & yes & 0 & $\begin{array}{l}\text { Direction } \\
\text { Specification } \\
\text { Method }\end{array}$ & 1 \\
\hline $\begin{array}{l}\text { ENABLE SHELL } \\
\text { CONDUCTION? }\end{array}$ & yes & 0 & $\begin{array}{l}\text { (profile } \\
\text { boundary } \\
\text { temp) }\end{array}$ & & \\
\hline
\end{tabular}




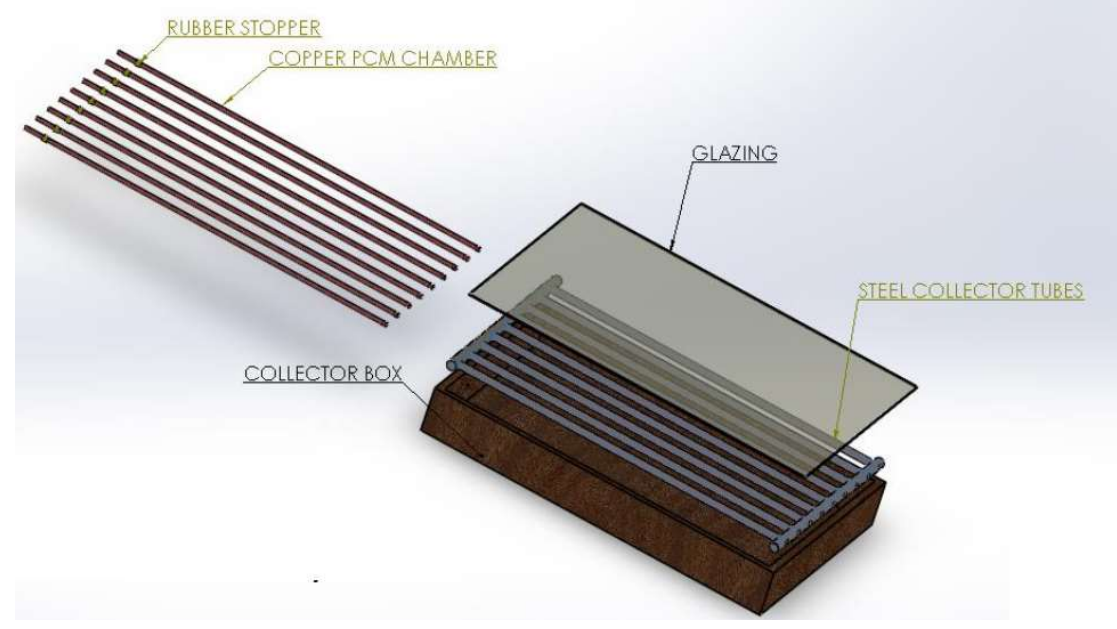

Figure 1. CFD Model geometry using ANSYS

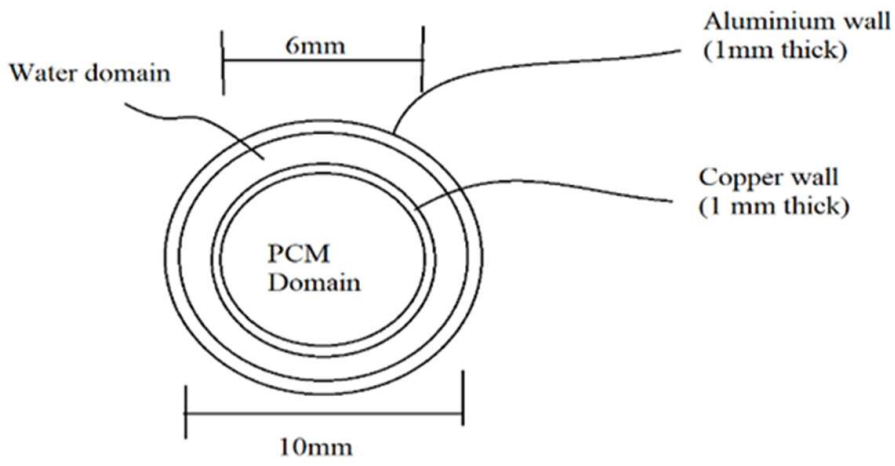

Figure 2. Simulation problem description

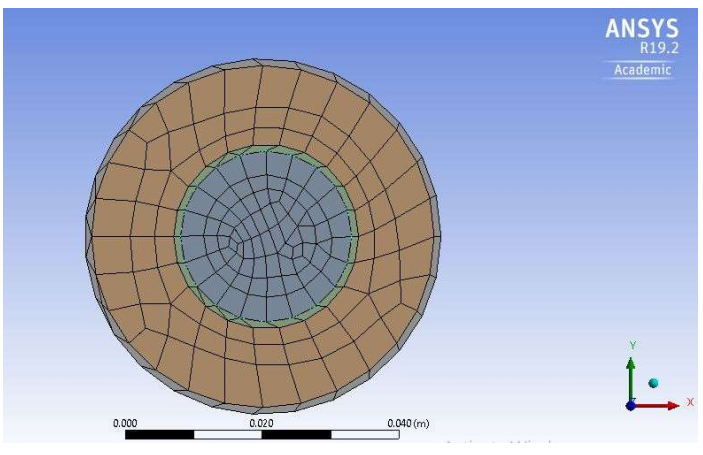

Figure 3. Two-dimensional view of absorber tube geometry meshed using ANSYS 


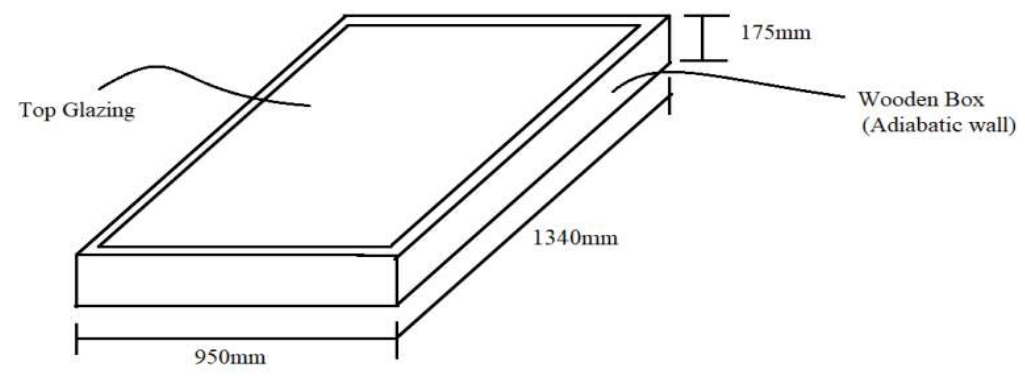

Figure 4. Collector box model geometry

\section{Results and Discussion}

The results obtained from both the experimental and numerical studies, show that all the organic PCMs tested gave good performances during the testing period. However, their characteristic melting points affected their performance in terms of hot water delivery during the day and night hours. Stearic acid showed highest temperatures during the day, giving temperatures of about $60^{\circ} \mathrm{C}$ as at $15: 00 \mathrm{hrs}$. However, it was noticed that stearic acid lost its heat rapidly since most of its heat was stored as sensible heat. This was shown by its rapid discharge during evening hours. It gave temperatures of $26.61^{\circ} \mathrm{C}$ as at $20: 00 \mathrm{hrs}$. Palmitic acid also showed good performances during the hours of the day, delivering hot water of about $54^{\circ} \mathrm{C}$ as at $14: 30 \mathrm{hrs}$. It showed better heat retention properties than stearic acid, as its discharge rate was slower. This can be observed from the graphs shown above. Myristic acid showed good performances during the hours of the day, however, its low melting point of about $55^{\circ} \mathrm{C}$ led to a relatively lower peak temperature of hot water discharge of about $46.5^{\circ} \mathrm{C}$ as at $15: 00 \mathrm{hrs}$. Myristic acid showed a flatter discharge slope, since it was able to store a significant amount of heat in its sensible form. It was able to deliver hot water of about $32^{\circ} \mathrm{C}$ as at $20: 00 \mathrm{hrs}$. Cetyl alcohol charged at a faster rate than it discharged. causing it to attain its maximum delivery temperature at a relatively shorter time than the other PCMs. This can be attributed to its low density of $940 \mathrm{~kg} / \mathrm{m}^{3}$, and its low melting point. Cetyl alcohol, however, did not allow for high hot water temperature delivery during the hours of the afternoon, as most of the heat absorbed by the water from the sun was used in the charging of the PCM, which was a similar occurrence with Myristic acid. The maximum hot water temperature recorded was about $50.68^{\circ} \mathrm{C}$ which was obtained at $13: 30 \mathrm{hrs}$. It was able to retain a temperature of $33^{\circ} \mathrm{C}$ as at $19: 00 \mathrm{hrs}$.

\subsection{Validation of simulation results}

Two steps were employed in the validation of the simulation model. The first method employed the graphical comparison of the trends of data obtained from both the experimental and numerical approaches.

The second method made use of the Root Means Square Method and the Nash Sutcliffe Error Coefficient method, for quantifying the accuracy of the simulation model. 


\subsubsection{Experimental and simulated temperature response validation results}

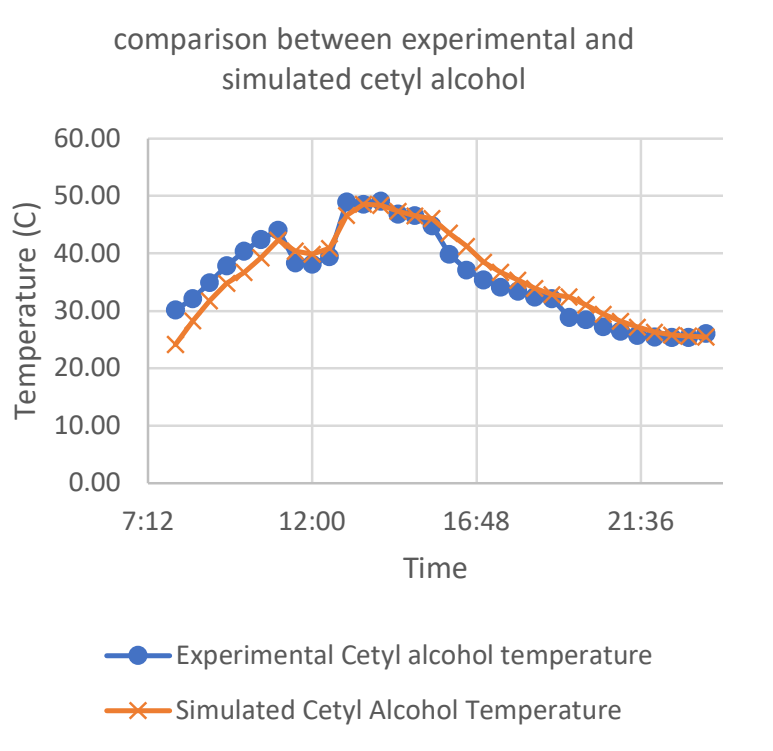

Figure 5. Comparison between simulated and experimental Cetyl Alcohol temperatures

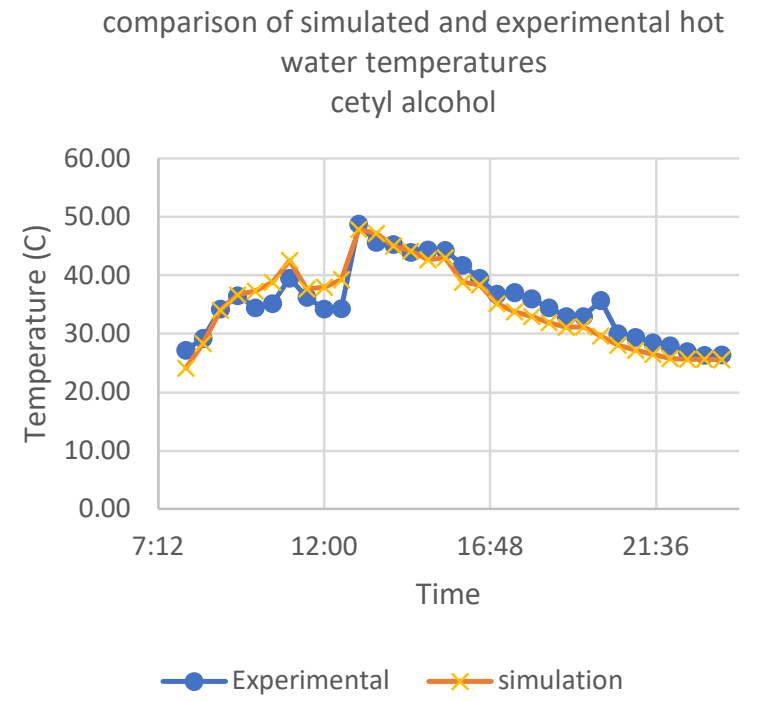

Figure 6. Comparison between simulated and experimental myristic acid temperatures 


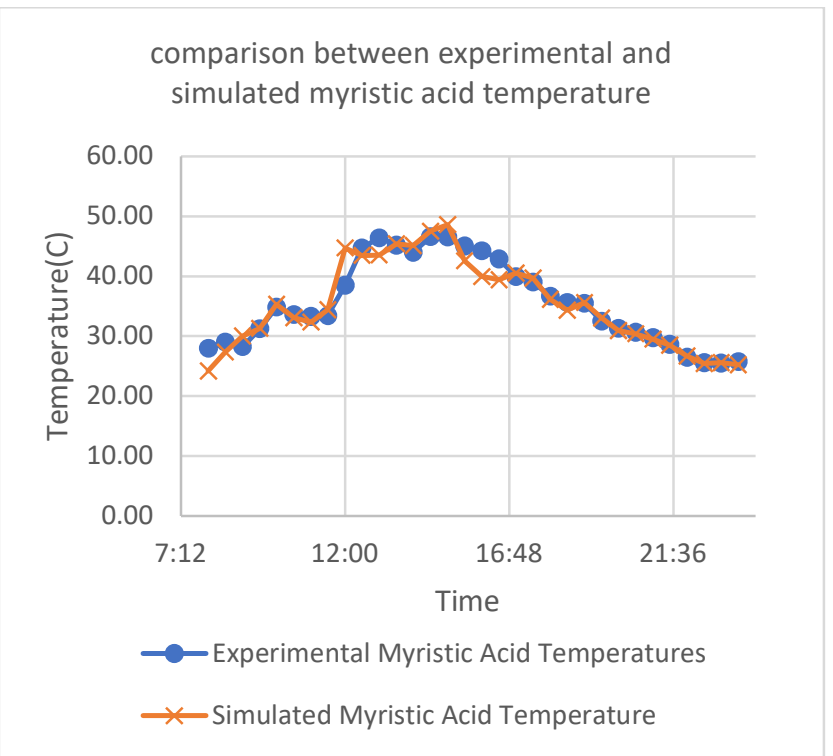

Figure 7. Comparison between simulated and experimental myristic acid temperatures

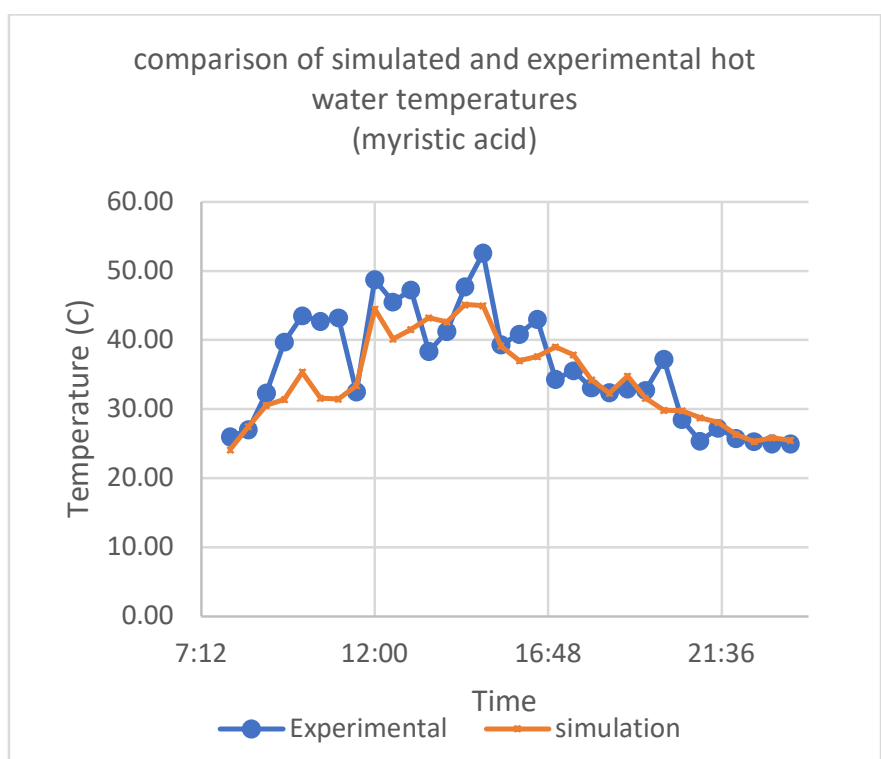

Figure 8: Comparison between simulated and experimental hot water temperatures (Myristic Acid) 


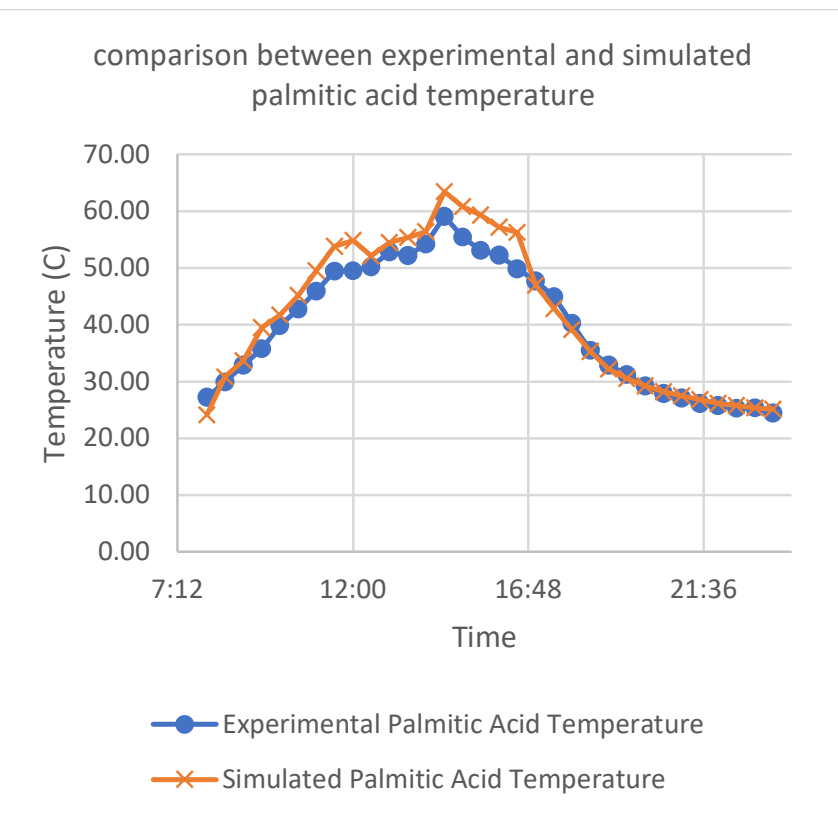

Figure 9. Comparison between experimental and Simulated Palmitic Acid temperatures.

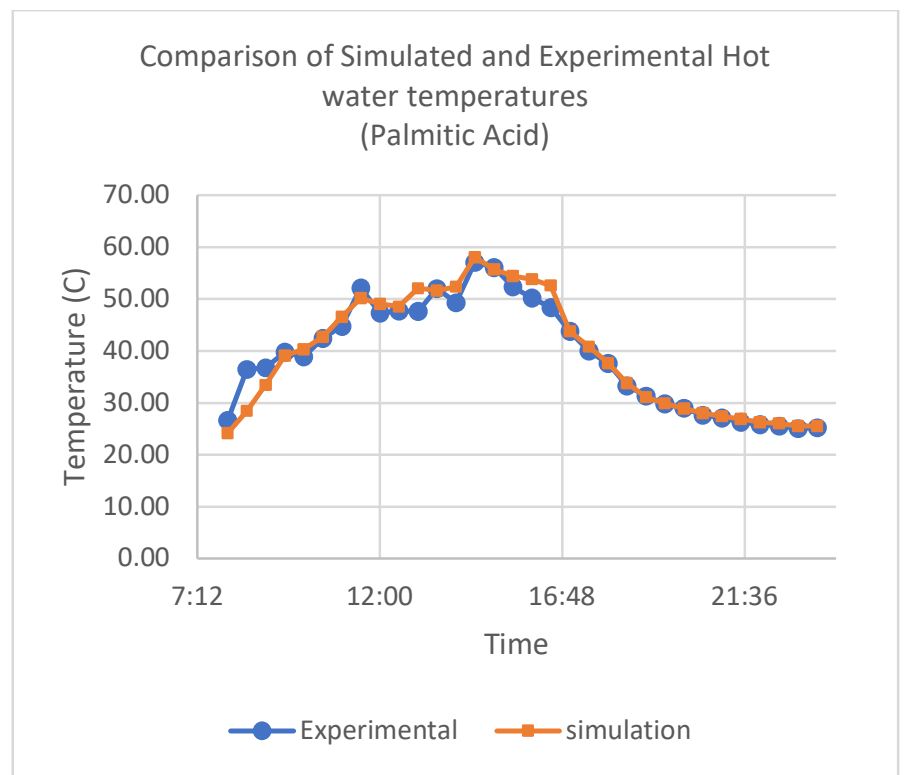

Figure 10. Comparison between experimental and Simulated Hot water temperatures (Palmitic Acid) 


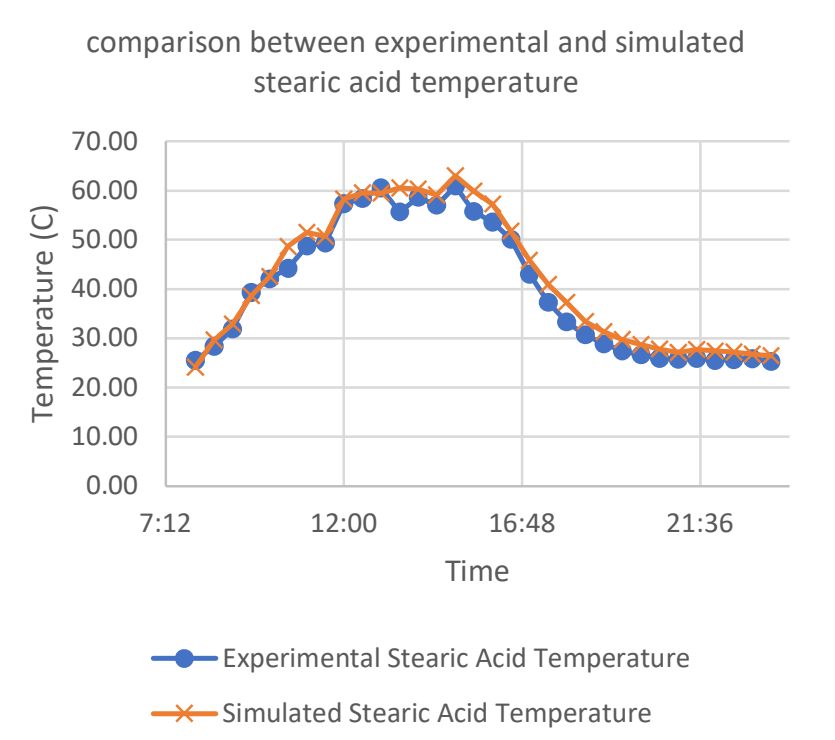

Figure 11. Comparison between experimental and Simulated Hot water temperatures (Stearic Acid)

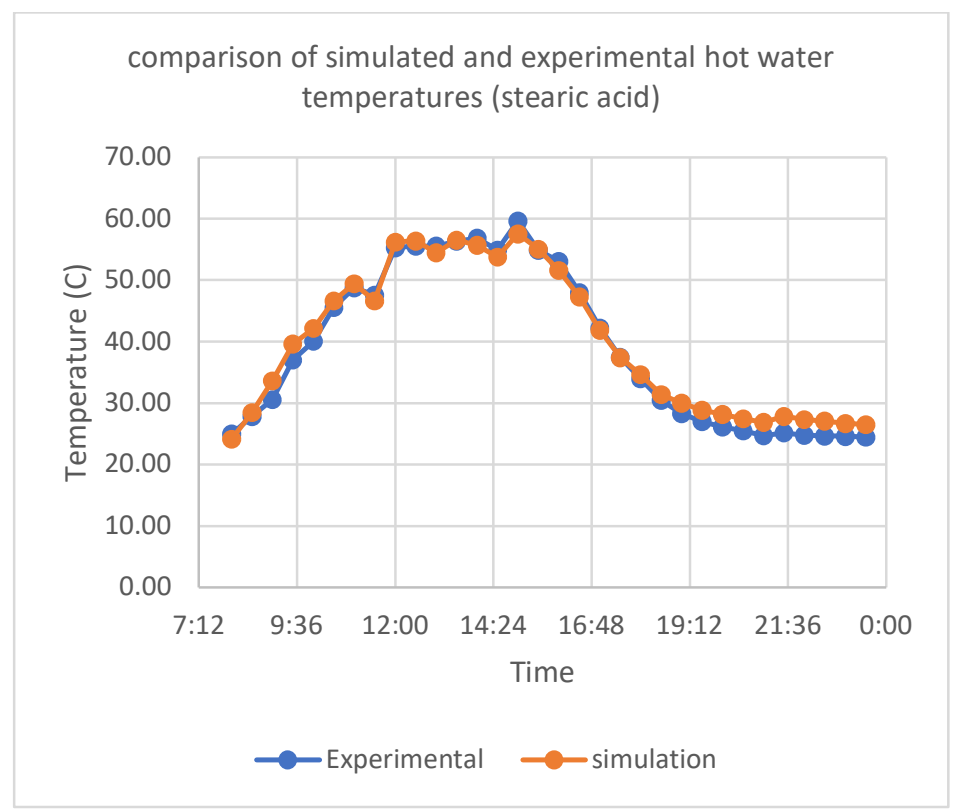

Figure 12. Comparison between experimental and Simulated Hot water temperatures (Stearic Acid)

Table 4: Validation results obtained using RMSE and NSE statistical validation techniques for PCM and hot water temperatures.

\begin{tabular}{|l|l|l|l|}
\hline PCM & DATA SET & RMSE $\left({ }^{\circ} \mathrm{C}\right)$ & NSE correlation \\
\hline Cetyl Alcohol & Cetyl Alcohol temperature & 2.494566866 & 0 \\
\cline { 2 - 4 } & Hot water Temperature & 2.447630459 & 0.995391 \\
\hline \multirow{2}{*}{ Myristic Acid } & Myristic Acid Temperature & 2.447630459 & 0.995391 \\
\cline { 2 - 4 } & Hot water Temperature & 4.753641598 & 0.983387 \\
\hline Palmitic Acid & Palmitic Acid & 2.940409376 & 0 \\
\cline { 2 - 4 } & Hot water Temperature & 2.250931652 & 0.996907 \\
\hline Stearic Acid & Stearic Acid temperature & 2.390451483 & 0 \\
\cline { 2 - 4 } & Hot water Temperature & 1.641203468 & 0.99841 \\
\hline
\end{tabular}


3.2 Simulation of Performance of solar water heater with PCMs operating under the same collector box temperatures.

In order to make better comparative assessments, the inconsistencies in weather conditions during the testing periods of the various PCMs were accounted for, by assuming that the various systems operated simultaneously under the same weather conditions using five different solar water heaters of the same efficiency. The simulation was performed using the now validated CFD model, and the average collector box temperatures measured during the six-week testing period were used as temperature boundary conditions on the external surface of the absorber tubes for the CFD model. The results obtained are presented in the graphs obtained below.

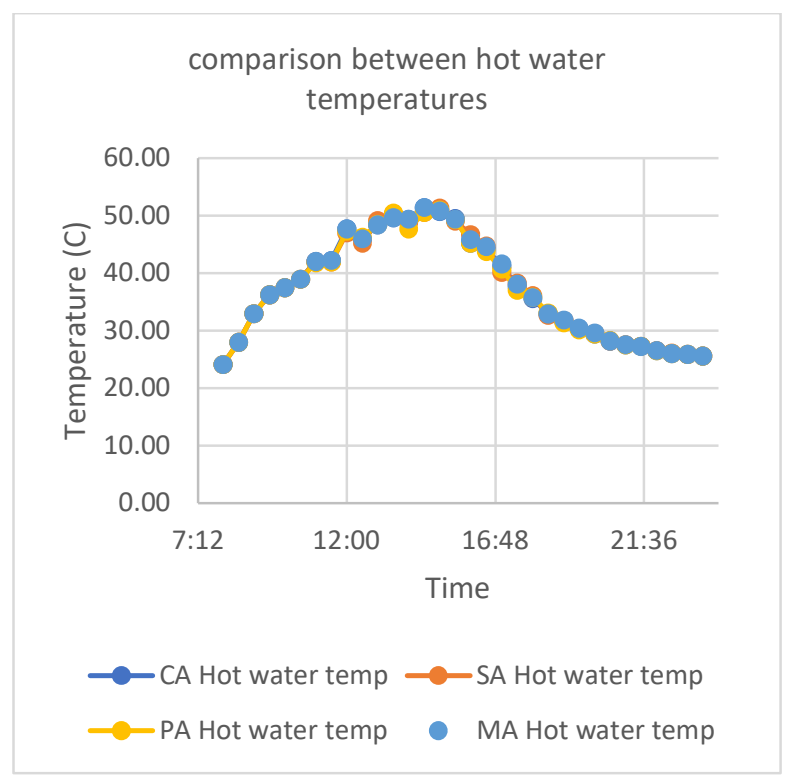

Figure 13. Simulation comparison of PCM temperatures using average collector box temperatures measured.

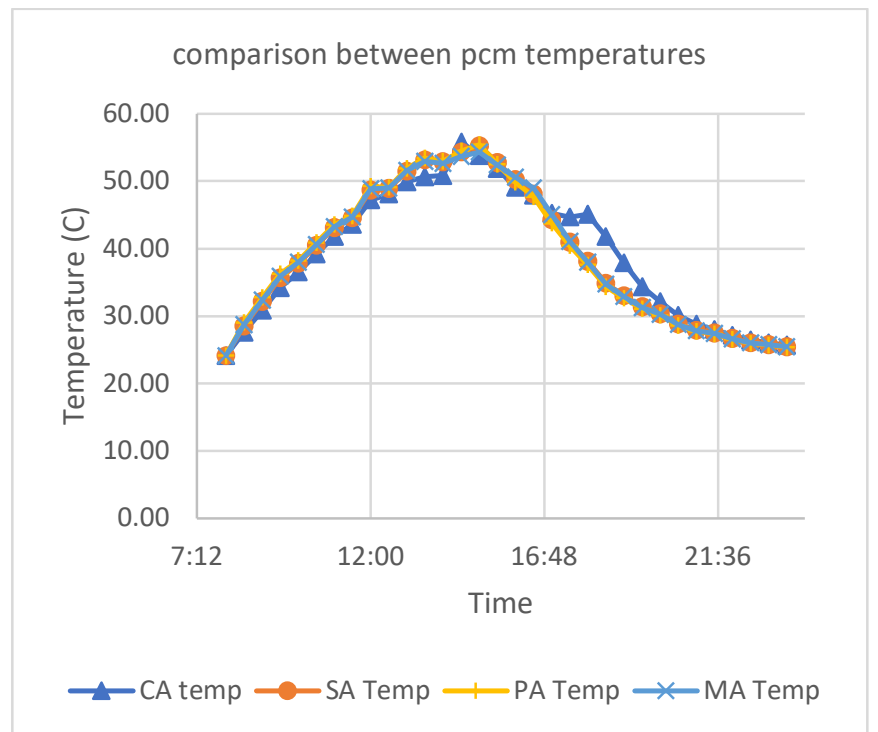

Figure 14. Simulation comparison of PCM temperatures using average collector box temperatures measured during the entire testing period 


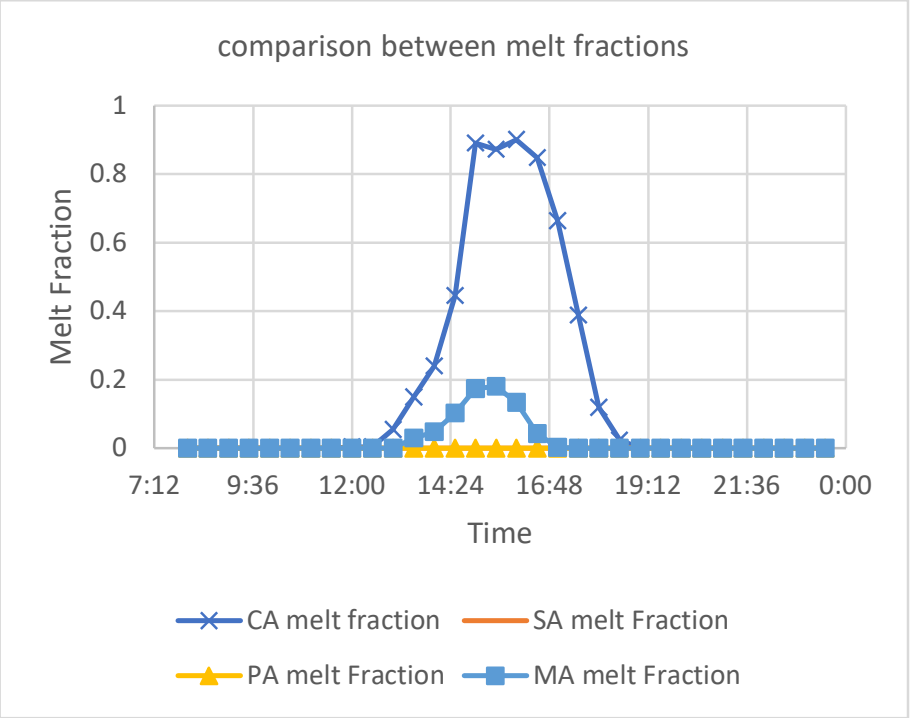

Figure 15. Simulation comparison of PCM temperatures using average collector box temperatures measured

The simulation results showed that under the same collector box temperatures, the hot water temperatures were similar for all the phase change materials during the operating hours. However, the charging and discharging performances varied during the simulation hours for each PCM. Cetyl alcohol showed the best performance in terms of thermal energy storage during the operation hours as it remained at a temperature of about $38^{\circ} \mathrm{C}$ at 19:00hrs as shown in Figure 14. At this temperature, the system charge at relatively low collector box temperatures thus able to store a reasonable amount of energy in terms of latent heat. This is evident by the relatively flat temperature profile that cetyl alcohol showed during charging. Major differences in hot water temperatures were not prominent in the system when operating with the various PCMs from the study. This is probably due to the low thermal conductivities of the various organic PCMs used during the experiment. This caused the hot water temperatures to drop below the PCMs by a reasonable temperature difference. Highlighting the slow response of organic paraffins in dispatching stored heat to the hot water during low solar insolation hours, agrees with the works of (Kumar et al., 2018). Further research in the enhancement of the thermal conductivities of these PCMs using nano particles are also being studied by other researchers.

\section{CONCLUSION}

The thermal operation of a solar water heater in Nsukka region, (Latitude $6.854^{\circ} \mathrm{N}$ longitude $7.29^{\circ} \mathrm{E}$ ), has been studied experimentally and numerically, and both methods gave similar results. The testing period of the study was characterized by rainy weather conditions, and the experimental research was limited to the prevalent weather conditions of the season. From the results of this research the following conclusions can be made:

1. The thermal energy storage materials that made use of their latent heat storage capacities generally gave better performances in terms of heat retention into the hours of the night. Cetyl Alcohol showed good charging and discharging performances under the prevalent weather conditions than the other phase change materials due to its relatively low melting temperature of about $50^{\circ} \mathrm{C}$. It was able to retain a temperature of about $38^{\circ} \mathrm{C}$ as at 19:00hrs.

2. A numerical model implemented with ANSYS FLUENT CFD software package as detailed in this work can be used to predict the behaviour of solar water heaters with an accuracy of about $98 \%$ which is well within the acceptable error limit according to (Zwalnan 2015).

3. The RMSE statistical validation tool gave an average error of $3.05^{\circ} \mathrm{C}$ for $\mathrm{PCM}$ temperatures and $3.64^{\circ} \mathrm{C}$ for hot water output temperatures. The Nash Sutcliffe Efficiency gave values approximately 0.95 for the PCMs and 0.98 for hot water temperatures. This means that the model predicts the performance of the PCMs and hot water with an accuracy of $95 \%$ and $98 \%$ respectively.

4. The NSE values of 0 observed in the table indicate that the CFD model is as accurate as the mean of the experimental data. while values of 1 indicate that the model can be used to perfectly forecast the trends in the experimental data.

\section{References}

[1] S. Amin and N. Nuarey Mithila, "The Importance of Using Solar Water Heater as an Alternative Eco- 
Friendly Technology in Global Market: Some Lessons of Experiences for Bangladesh Economy," Ssrn, pp. 1-47, 2017.

[2] J. Lizana, R. Chacartegui, A. Barrios-Padura, J. M. Valverde, C. Ortiz, and C. Ortiz, Identification of best available thermal energy storage compounds for low-to-moderate temperature storage applications in buildings, vol. 68, no. 331. 2018.

[3] T. H. Kean, N. A. C. Sidik, Y. Asako, T. L. Ken, and S. R. Aid, "Numerical study on heat transfer performance enhancement of phase change material by nanoparticles: a review," J. Adv. Res. Fluid Mech. Therm. Sci., vol. 45, no. September, pp. 55-63, 2018.

[4] I. H. Zarma, "Thermal Energy Storage in Phase Change Materials:-Applications, Advantages and Disadvantages," Int. J. Chem. Eng. Appl., no. November, 2017.

[5] S. Dirbude, "Numerical assessment of suitability of phase-change materials in a concentric PCM-module for thermal storage applications Numerical assessment of suitability of phase-change materials in a concentric PCM-module for thermal storage applications," no. November, 2018.

[6] E. Umeh, "Design, Construction of A PCM Packed Solar Water Heater," A B.Eng Project Submitted to the Department of Mechanical Engineering, University of Nigeria, Nsukka. August, 2018.

[7] J. Jonsson, "Masters Thesis" Including Solar Load in CFD Analysis of Temperature Distribution in a Car Passenger Compartment," 2007. 